\title{
Hubungan Status Gizi terhadap Perkembangan Motorik pada Anak Usia 6-24 Bulan
}

\author{
Tuhu Perwitasari ${ }^{1}$, Melda Amalia ${ }^{2}$ \\ ${ }^{1,2}$ Prodi D III Kebidanan STIKes Baiturrahim Jambi \\ Email: tuhuedie@ymail.com
}

Submitted : 11/02/2021

Accepted: 10/09/2021

Published: 15/09/2021

\begin{abstract}
The quality of human resources is related to the quality of children, where the quality of children today has an impact on the quality of human resources in the future. The number of sufferers of malnutrition and malnutrition is around $28 \%$ of the total children under five in Indonesia. About $10 \%$ of children under five who suffer from malnutrition and lack of nutrition end up dying. The under-five mortality rate is 37 per 1,000, half of which is due to malnutrition. This study was conducted to determine the relationship between nutritional status and motoric development in children aged 6-24 months. This study used an analytic observational design with a cross sectional approach. The subjects of this research were all mothers and toddlers who came to the low stinger Integrated health-service post (POSYANDU) in the work area of the Aur Duri's public health center (PUSKESMAS), namely 30. The measuring instruments used were the dacin weight balance, microtoise and KPSP scales. Bivariate analysis using chi-square. The results of the study which is mostly under five year old children in aged 13-24 months and male gender is 36.7\%. The most nutritional status ( $B W / U$ ) in children aged 6-24 months is Good Nutrition with the male gender, namely 53.4\%. The development of children aged 6-24 months at most was normal, with 8 male respondents (26.7\%). The conclusion yields there is no significant relationship between the levels of nutritional status of children under five years old with the development of children. It is expected that parents will increase stimulations. Health workers and cadres should be included in training so that they can measure progress with the KPSP.
\end{abstract}

Keywords: children, motor development, nutritional status

\begin{abstract}
Abstrak
Kualitas sumber daya manusia berhubungan dengan kualitas anak, dimana kualitas anak masa kini berdampak terhadap kualitas sumber daya manusia yang akan datang. Jumlah penderita gizi buruk dan gizi kurang ini sekitar 28\% dari total balita di seluruh Indonesia. Jumlah balita penderita gizi buruk dan kurang, sekitar 10\% berakhir dengan kematian. Angka kematian balita yaitu 37 per 1.000 ini, separuhnya adalah disebabkan oleh kekurangan gizi. Penelitian ini dilakukan untuk mengetahui hubungan status gizi terhadap perkembangan motorik pada anak usia 6-24 bulan. Penelitian ini menggunakan desain observasional analitik dengan pendekatan cross sectional. Subjek penelitian ini adalah seluruh ibu dan balita yang datang ke posyandu penyengat rendah wilayah kerja puskesmas aur duri yaitu sebanyak 30. Alat ukur yang digunakan adalah timbangan dacin, microtoise dan KPSP. Analisis bivariat menggunakan chi-square. Hasil penelitian balita terbanyak berusia 13-24 bulan dan jenis kelamin laki-laki sebayak 36.7\%. Status gizi (BB/U) yang paling banyak pada anak usia 6-24 bulan adalah Gizi Baik dengan jenis kelamin laki-laki yakni $53.4 \%$. Perkembangan balita usia 6-24 bulan yang paling banyak adalah normal yakni dengan 8 responden laki-laki (26.7\%). Kesimpulan bahwa tidak ada hubungan yang signifikan antara tingkat status gizi balita dengan perkembangan balita. Diharapkan orang tua lebih meningkatkan stimulasi. Tenaga kesehatan dan kader sebaiknya diikutsertakan dalam pelatihan sehingga dapat melakukan pengukuran perkembangan dengan KPSP.
\end{abstract}

Kata Kunci: anak, perkembangan motorik, status gizi 


\section{PENDAHULUAN}

Faktor yang berpengaruh terhadap proses pertumbuhan anak adalah status gizi yang menentukan keberhasilan dalam peningkatan kualitas sumber daya manusia. Penyebab utama kematian anak balita adalah masalah gizi buruk dengan angka 54 persen. Masalah gizi buruk dan kekurangan gizi merupakan masalah utama kesehatan di Negara berkembang seperti Indonesia (Kementrian Kesehatan RI, 2013).

Pada masa balita apabila mengalami kekurangan gizi mengakibatkan terjadinya keterlambatan atau terganggunya proses pertumbuhan, perkembangan otak dan menurunnya daya tahan tubuh terhadap infeksi. Kekurangan gizi juga berakibat terjadinya anemia pada balita sehingga akan meningkatkan angka morbiditas dan mortalitas pada balita. Hasil penelitian yang dilakukan terhadap suku anak dalam di Kabupaten Musi Bayuasin propinsi Sumatra Selatan masih terdapat 84 persen anak dari usia 0-9 tahun yang mengalami anemia (Sitorus, 2011).

Pertumbuhan dan perkembangan pada tahap awal menentukan perkembangan selanjutnya. Salah satu parameter perkembangan anak adalah perkembangan motorik kasar yaitu aspek yang berhubungan dengan pergerakan dan sikap tubuh yang melibatkan otot-otot besar (IDAI, 2010). Pola asuh sangat mempengaruhi pertumbuhan tetapi perbedaan pola asuh makan antar etnis terkadang tidak mempengaruhi pertumbuhan. Pertumbuhan anak yang tidak normal pada setiap tingkatan umur sangat berpengaruh terhadap perkembangan motoriknya (Perwitasari, 2019)

Jumlah kasus gizi buruk pada tahun 2016 di provinsi Jambi sebanyak 75 orang, 44 anak laki-laki dan 31 orang perempuan dan meninggal 3 orang. Pada tahun 2017, jumlah kasus gizi buruk terjadi peningkatan kasus gizi buruk sebanyak 85 orang anak, 39 orang laki-laki dan 45 anak perempuan. Pada tahun 2018 jumlah kasus gizi buruk sebanyak 75 orang anak. Berdasarkan fenomena diatas penulis tertarik melakukan penelitian tentang hubungan status gizi terhadap perkembangan motorik pada anak usia 6-24 bulan di Wilayah Kerja Puskesmas Aur Duri Kota Jambi.

\section{METODE PENELITIAN}

Penelitian ini menggunakan desain observasional analitik dengan pendekatan cross sectional. Dilakukan di Wilayah Kerja Puskesmas Aur Duri. Subjek penelitian ini adalah semua ibu dan balita yang datang ke posyandu yaitu sebanyak 30. Ibu dan anak sebelum menjadi Subjek penelitian telah dilakukan informed consent. Alat ukur yang digunakan adalah timbangan dacin, microtoise dan KPSP. Alat yang digunakan telah dikalibrasi. Analisa data dilakukan secara univariat dan bivariat dengan uji chi-square.

\section{HASIL DAN PEMBAHASAN \\ Status Gizi Anak Usia 6-24 Bulan}

Tabel 1. Distribusi Jumlah Anak 6-24

Bulan Menurut Status Gizi

\begin{tabular}{lcccc}
\hline \multirow{2}{*}{\begin{tabular}{c} 
Status Gizi \\
\multicolumn{1}{c}{$(\mathrm{BB} / \mathrm{U})$}
\end{tabular}} & \multicolumn{4}{c}{ Peremis Kelamin } \\
& $\mathrm{n}$ & $\%$ & $\mathrm{n}$ & $\%$ \\
\hline Gizi Buruk & 0 & 0 & 0 & 0 \\
Gizi Kurang & 0 & 0 & 4 & 13.3 \\
Gizi Baik & 9 & 30 & 16 & 53.4 \\
Gizi Lebih & 0 & 0 & 1 & 3.3 \\
Jumlah & 9 & 30 & 30 & 70 \\
\hline
\end{tabular}

Dari tabel 1 diketahui bahwa yang paling banyak status gizi anak usia 6-24 Bulan berdasarkan indikator $\mathrm{BB} / \mathrm{U}$ adalah Gizi Baik dengan jenis kelamin laki-laki yakni $53.4 \%$. Sedangkan yang paling sedikit dengan status gizi $(\mathrm{BB} / \mathrm{U})$ yakni Gizi Lebih (3.3\%) dengan jenis kelamin laki-laki.

Perkembangan anak usia 6-24 bulan

Tabel 2. Distribusi Jumlah Anak 6-24 Bulan Menurut Perkembangan Anak Usia 6-24 Bulan 


\begin{tabular}{lcccc}
\hline \multirow{2}{*}{\begin{tabular}{c} 
Perkembangan \\
\multicolumn{1}{c}{ Balita }
\end{tabular}} & \multicolumn{4}{c}{ Penis Kelamin } \\
& $\mathrm{n}$ & $\%$ & $\mathrm{n}$ & $\%$ \\
\hline Meragukan & 3 & 10 & 7 & 23.3 \\
Normal & 6 & 20 & 8 & 26.7 \\
Abnormal & 1 & 3.3 & 5 & 16.7 \\
Jumlah & 10 & 33.3 & 20 & 66.7 \\
\hline
\end{tabular}

Berdasarkan tabel 2 didapatkan hasil bahwa yang paling banyak perkembangan anak usia 6-24 Bulan adalah normal yakni dengan 8 responden laki-laki (26.7\%), sedangkan yang paling sedikit dengan perkembangan anak yakni abnormal $(3.3 \%)$ dengan jenis kelamin perempuan.

\begin{tabular}{|c|c|c|c|c|c|c|c|}
\hline \multicolumn{8}{|c|}{$\begin{array}{l}\text { Hubungan Status Gizi } \text { dengan } \\
\text { Perkembangan Anak 6-24 Bulan } \\
\text { Tabel 3 Distribusi frekuesi Hubungan } \\
\text { Status Gizi dengan Perkembangan Anak 6- } \\
24 \text { Bulan }\end{array}$} \\
\hline \multirow{3}{*}{$\begin{array}{c}\text { Status } \\
\text { Gizi }\end{array}$} & \multicolumn{6}{|c|}{ Perkembangan Anak } & $\begin{array}{c}\mathrm{P} \\
\text { valu }\end{array}$ \\
\hline & \multicolumn{2}{|c|}{$\begin{array}{c}\text { Meraguka } \\
n\end{array}$} & \multicolumn{2}{|c|}{ Normal } & \multicolumn{2}{|c|}{$\begin{array}{c}\text { Abnorma } \\
1\end{array}$} & \\
\hline & $f$ & $\%$ & $\mathrm{f}$ & $\%$ & $\mathrm{f}$ & $\%$ & \\
\hline $\begin{array}{l}\text { Gizi } \\
\text { Kuran }\end{array}$ & 1 & 3.3 & 2 & 6.7 & 1 & 3.3 & $\begin{array}{l}\mathrm{p}= \\
0,70\end{array}$ \\
\hline $\begin{array}{l}\mathrm{g} \\
\text { Gizi } \\
\text { Baik }\end{array}$ & 8 & 26.7 & $\begin{array}{l}1 \\
2\end{array}$ & 40 & 5 & 16.7 & \\
\hline $\begin{array}{l}\text { Gizi } \\
\text { Lebih }\end{array}$ & 1 & 3.3 & 0 & 0 & 1 & 3.3 & \\
\hline Total & 10 & 33.3 & $\begin{array}{l}1 \\
4 \\
\end{array}$ & $\begin{array}{l}46 . \\
7\end{array}$ & 6 & 20 & \\
\hline
\end{tabular}

Berdasarkan tabel 3 frekuensi hubungan status gizi dengan perkembangan motorik anak 6-24 bulan diketahui bahwa sebagian besar subjek memiliki perkembangan normal dengan status gizi baik yaitu sebanyak $40 \%$. hasil uji bivarian dengan chi-square didapatkan hasil tidak ada hubungan antara status gizi yang signifikan terhadap perkembangan anak dengan nilai $\mathrm{p}=0.70$.

Menurut Soejitningsih perkembnagan anak dipengaruhi oleh faktor internal dan eksternal. Faktor eksternal meliputi faktor prantal, natal dan post natal.
Faktor post natal meliputi Asupan Gizi, status gizi, Pola pengasuhan, dan pengetahuan orang tua.

Penelitian ini tidak sejalan dengan penelitian Sulistyorini (2020) terhadap hubungan status gizi terhadap perkembangan motorik anak prasekolah. Sehingga peningkatan pengetahuan orang tua dan guru untuk memberikan stimulasi yang sesuai dengan perkembangan anak dan edukasi tentang nutrisi yang sehat untuk anak.

\section{Pembahasan}

Pada hasil penelitian ini masih dijumpai masalah gizi seperti gizi kurang dan gizi lebih. Hal tersebut mungkin disebabkan oleh asupan gizi balita karena kurangnya perhatian orang tua akan asupan dan nilai gizi makanan yang diberikan kepada balita. Tidak terdapat perbedaan signifikan pada Jenis kelamin terhadap status gizi seseorang. Tetapi anak dari lingkungan perkotaan akan lebih dekat dengan gizi lebih bahkan obesitas dibanding dengan anak yang tinggal dilingkungan pedesaan (Djoric, 2020)

perkembangan anak usia 6-24 Bulan adalah normal yakni dengan 8 responden laki-laki (26.7\%), sedangkan yang paling sedikit dengan perkembangan anak yakni abnormal (3.3\%) dengan jenis kelamin perempuan. perkembnagan anak dipengaruhi oleh factor internal dan eksternal. Faktor eksternal meliputi factor prantal, natal dan post natal. Faktor post natal meliputi Asupan Gizi, status gizi, Pola pengasuhan, dan pengetahuan orang tua (soejitningsih, 2012).

perkembangan anak usia 6-24 Bulan adalah normal dengan jenis kelamin lakilaki, sedangkan yang paling sedikit dengan perkembangan anak yakni abnormal dengan jenis kelamin perempuan. faktor yang mempengaruhi perkembangan faktor genetik dan faktor lingkungan. Salah satunya interaksi orang-tua ke anak. Interaksi timbal balik antara anak-orangtua akan menimbulkan keakraban dalam 
keluarga yang dari hubungan ini akan memudahkan orangtua terutama ibu untuk memberikan stimulasi kepada anak. Tidak ada hubungan yang signifikan antara tingkat status gizi balita dengan perkembangan di posyandu wilayah kerja Puskesmas Aur Duri, sehingga semakin baik status gizi anak belum tentu semakin baik perkembangannya. Adanya faktor tidak langsung yang diduga ikut berperan sebagai variabel perancu dalam penelitian ini, sehingga memberikan hasil yang tidak significant antara tingkat status gizi dengan perkembangan pada anak usia 6-24 bulan seperti pengetahuan ibu, pendikan ibu dan interaksi antara ibu-anak.

Hal ini sesuai dengan penelitian Gladdy dkk ( 2011) dengan judul Hubungan status gizi dengan perkembangan anak usia 1-2 tahun tidak ada hubungan antara status gizi dengan perkembangan anak usia 1-2 tahun dengan nilai $\mathrm{p}=0,394$. Menurut gladdy dkk (2011) pendidikan orang tua berpengaruh terhadap perkembangan anak terutama pendidikan ibu. Pendidikan ibu yang rendah mempunyai risiko untuk terjadinya keterlambatan perkembangan anak, disebabkan ibu belum tahu cara memberikan stimulasi perkembangan anaknya. Ibu dengan pendidikan lebih tinggi lebih terbuka untuk mendapat informasi dari luar tentang cara pengasuhan anak yang baik, menjaga kesehatan, dan pendidikan anak

\section{SIMPULAN}

Tidak ada hubungan yang signifikan antara tingkat status gizi balita terhadap perkembangan anak

\section{SARAN}

Diharapkan Ibu dapat meningkatkan stimulasi dan interaksi antara orang tuaanak sehingga dapat meningkat perkembangan anak dan bidan desa bahkan kader sebaiknya diikutkan sertkan pelatihan dimana diajarkan cara penggunaan KPSP, sehingga baik bidan atau kader dapat sendiri melakukan pengukuran perkembangan dengan KPSP.

\section{UCAPAN TERIMAKASIH}

Ucapan trimakasih yang tak terhingga pada kepala puskesmas Aur Duri Kota Jambi yang telah memberikan izin, Tim penelitian, seluruh subjek penelitian dan kepada STIKes Baiturrahim Jambi atas bantuan dana dan fasilitas.

\section{DAFTAR PUSTAKA}

Djoric, C. Vukicevic, V. 2020. Nutritional Status of Young School Children in a Rural Environment in Srem District. Journal Of Anthropology Of Sport And Physical Education. Novi Sad, Serbia

Perwitasari, T. 2019. Hubungan Pola Asuh dengan Pertumbuhan Anak 6-24 Bulan (Studi Perbandingan Antara Suku Melayu Jambi dan Suku Jawa Di Kabupaten Muaro Jambi Propinsi Jambi). Jurnal ilmiah universitas batanghari jambi. Jambi.

Sitorus, H. Oktarina, R. Ambarita, PL. 2011. Malaria Pada Anak di Desa Pagar Desa (Pemukiman Suku Anak Dalam) di Kabupaten Musi Banyuasin Propinsi Sumatera Selatan. Media Litbang Kesehatan Volume 21. Palembang.

Soejitningsih, dr. 2012. Tumbuh Kembang Anak. Jakarta: EGC

Sulistyorini. 2020. Analisis status gizi terhadap perkembangan motorik pada anak prasekolah. Jurnal ilmiah multi science kesehatan. Palembang. 